\title{
Electronic Will
}

\section{Murat Oruç}

\begin{abstract}
When the existence of a personality ends with death, the assets of the deceased continue to exist. In such a case, what should be the status of the assets of the deceased; whether the testator has a freedom in this regard? And if he or she has such a freedom, how should it be used? These are the questions to be answered. Modern legal systems award a partial or total freedom to individuals on how to distribute the assets after the death of the testator. These legal systems differ in terms of how to use this freedom, i.e. in which form should the declaration of intention be expressed. However, in the case of electronic wills, which are the main topic of our article, such differentiation disappears. This is because the majority of legal systems do not contain any legal provisions for electronic wills and this absence makes all of them share a common ground: despite not being regulated by law, the increase in electronic will related conflicts shows that this subject needs to be examined thoroughly. For this reason, the electronic will has been selected as the topic of this article and the regulations, draft law and judicial decisions regarding the e-Will will be analyzed in detail. Then, this topic will be examined in the context of Turkish law and the question whether the electronic will is valid or not will be discussed.
\end{abstract}

\section{Keywords}

Probate $\bullet$ Will $\bullet$ e-Will $\bullet$ Validity conditions $\bullet$ Legal status $\bullet$ Case law

\section{Elektronik Vasiyetname}

\section{Öz}

Ölümle kişilik sona erer fakat ölen kişinin malvarlığı mevcudiyetini sürdürür. Ölen kişinin malvarlığının akıbetinin ne olacağı, bu konuda murisin bir özgürlüğe sahip olup olmadı̆̆ı, böyle bir özgürlüğü var ise, bunu nasıl kullanacağı yanıtlanması gereken sorulardır. Modern hukuk sistemleri, ölümünden sonra malvarlığının nasıl dağıtılacağı hususunda murise kısmen ya da tamamen özgürlük tanımaktadır. Bu özgürlüğün nasıl kullanılacağı, yani irade beyanının hangi forma girmesi gerektiği hususunda ise, hukuk sistemleri farklılaşmaktadır. İnceleme konumuz olan elektronik vasiyetnamede ise, bu farklılaşmanın ortadan kalktı̆̆ını söyleyebiliriz. Çünkü hukuk sistemlerinin neredeyse hiçbirisinde elektronik vasiyetnameye ilişkin yasal bir düzenleme bulunmamaktadır ve bu durum hepsini ortak bir paydada buluşturmaktadır. Yasal bir düzenlemeye sahip olmamasına rağmen, elektronik vasiyetnameye ilişkin hukuki ihtilaflardaki artıs, konunun incelemeye muhtaç olduğunu göstermektedir. İşte bu sebeple, elektronik vasiyetname inceleme konusu olarak tercih edilmiş ve böylelikle elektronik vasiyetnamenin tanıtılması gayesi güdülmüştür. Bu amaçla öncelikle elektronik vasiyetnameye ilişkin düzenleme, tasarı ve yargı kararları incelenmiştir. Bunun ardından, meseleye Türk hukuku açısından yaklaşılmış ve elektronik vasiyetnamenin geçerli olup olmayacağı sorusuna yanıt aranmıştır.

\section{Anahtar Kelimeler}

Vasiyetnamenin tasdiki• Vasiyetname• e-Vasiyet• Geçerlilik koşulları• Hukuki nitelik• Yargı kararları

\footnotetext{
Correspondence to: Murat Oruç (Dr.), Fatih Sultan Mehmet Vakıf University, School of Law, Department of Civil Law, Istanbul, Turkey: Email: moruc@fsm.edu.tr

To cite this article: Oruç, Murat; “Electronic Will”, İstanbul Hukuk Mecmuası, 76/1, 2018, 205-219.
} 


\section{Introduction}

Technological developments not only brought new concepts to our lives but they also brought a requirement of re-defining existing concepts with new perspectives. When we consider innovations such as electronic signature, electronic contracts and electronic trade, it is possible to say that the law creates its own new concepts such as the electronic will. In this paper, we review the new concept of the electronic will, and then discuss the positive and the negative aspects of it as it brings with it many unanswered legal questions. It must be clarified whether a handwritten document, an electronically signed paper, a voice recorded on a smartphone or a video uploaded to a computer should be deemed as a valid will reflecting the last will and testament of the deceased. We look for answers to these questions within the boundaries of the Turkish Civil Law and we examine whether an electronically declared will can be considered valid and binding. We compare the specific regulations relating to the electronic will and the criticisms it is facing. Finally, landmark cases regarding electronic wills will be examined. The outcomes of this study will put both the de lege lata and the de lege ferenda offers together.

\section{Definition}

The Nevada Revised Statutes (hereinafter "NRS") $§ 133.119$, which is the only regulation on the issue of electronic wills, contains a definition. ${ }^{1}$ According to this provision, the "Electronic will means a testamentary document that complies with the requirements of NRS 133.085 ". NRS $\S 133.085$ explains that the electronic will is a type of testament, written, created and stored in an electronic medium. A similar approach is followed in the Electronic Wills Act Draft. ${ }^{2}$ Section 2 of the Draft gives this definition: "Electronic will means a will executed in compliance with Section 3". According to Draft sec. 3, the electronic will is a document, created by the will of making a testament, and containing the last wishes of the testator to be fulfilled after his or her death, and which is produced, transferred or stored in the electronic, digital, magnetic, optical or similar means, as allowed by technology.

The direct definition of electronic will was not given in both regulations, rather, the conditions of validity are cited. In our opinion, it is both beneficial and necessary to address the definition and the conditions of validity of the electronic will separately. In this context, the present author believes that it is possible to give a definition as follows: An electronic will is a type of testament that creates the orders and directives to be fulfilled after death by using a device that allows to create, record and store data through electronic, optical or similar means. 


\section{Advantages and Disadvantages}

\subsection{Advantages}

It is possible to summarize the advantages of the electronic will as follows:

- Exceptional circumstances require immediate action. In such cases, using a smartphone or an electronic device for the preparation of the electronic will is the only viable means for a person to transmit his or her last will. ${ }^{3}$

- Since everyone has a smartphone today, the electronic will is also a practical will. Moreover, just as with the holographic will, the electronic will is free of charge. ${ }^{4}$

- The risks of destroying or losing the holographic will almost disappear with the electronic will. Since there is no distinction of original-copy in electronic data, the risks of being lost or falsification by third parties are also avoided. ${ }^{5}$

- The testator preparing an electronic will has the possibility of expressing his or her last wishes in a better way. For this reason, the orders and directives of the testator can be determined in a simpler and sounder way in electronic will. ${ }^{6}$

\subsection{Disadvantages}

Despite the above advantages, the electronic will has some disadvantages. We can summarize the arguments against the electronic will as follows:

- The greatest criticism against the electronic will is that the form abrogates the functions of warning, protecting and being evidence. ${ }^{7}$ It cannot be said that this criticism is unfair. However, rather than turning back the developments in technology, it is better to update legal regulations to include the caution and warning functions in the electronic will.

- The electronic will is also criticized because of the involvement of unforeseeable security risks and the risk of fraud. ${ }^{8}$ It is said that the electronic will cannot be relied on during a time when the nation's most protected databases are hacked.

\footnotetext{
Jasmine Banks, "Turning won't into a will: Revisiting will formalities and e-filing as permissible solutions for electronic wills in Texas", Estate Planning \& Community Property Law Journal, no. 8 (2015), p. 298; Abdurrahman Savaş, "İnternet ortamında yapılan tek taraflı hukuki işlemler ve özellikle elektronik vasiyetname", Selçuk Üniversitesi Hukuk Fakültesi Dergisi, no.2 (2007), p. 79-80.

4 Banks, p. 298.

Savaș, p. 79.

Aydın Aybay, Miras hukuku dersleri (İstanbul, 2002), p. 34 fn. 2.

Joseph Karl Grant, "Shattering and moving beyond the Gutenberg Paradigm: The dawn of modern will", University of Michigan Journal of Law Reform, no. 42 (Fall 2008), p. 121-122.

8 Scott S. Boddery, "Electronic wills: Drawing a line in the sand against their validity", Real Property, Trust and Estate Law Journal, no. 1 (Spring 2012), p. 206-207.
} 
- Sometimes, it may be difficult to determine whether the data on an electronic device is the real and final will or a testamentary project. In an exceptional case, for example in terms of a video recording just before a suicide, such a problem does not occur, but in case of a video prepared in an ordinary situation it may be difficult to determine whether the video reflects the real intention or just fabricated for other purposes.

- Since the preparation of the electronic will eliminates the need of a legal advisor, it may also lead to a problem at the same time. ${ }^{9}$ A person having no knowledge of the law may lead to there being different interpretations due to using vague expressions (such a disadvantage is also present in the holographic will).

- Also the resistance of the legal advisors against change cannot be ignored. ${ }^{10}$ However, it should be noted that the same resistance against the electronic will today was shown against the holographic will 150 years ago. Indeed, the holographic will could only be included in the German Civil Code after long debates. ${ }^{11}$

\section{Legislation}

\subsection{Nevada Statute}

The first and only legal regulation concerning the electronic will belongs to the State of Nevada of the United States in 2001. With the amendment in the NRS, the paragraphs numbered 133.119 and 133.085 have been added to the Statutes and thus the electronic will gained a legal regulation for the first time. ${ }^{12}$ When the date of the amendment regarding the electronic will is considered, it is possible to say that the regulation is pioneering and groundbreaking. ${ }^{13}$ However, we should also note that there is criticism against it. ${ }^{14}$

The electronic will is defined in NRS $\S 133.119$ by making a reference to NRS $\S$ 133.085. In the aforementioned provision, it has been explained that the electronic will is a type of will that is created, written and stored in an electronic record. It has also been stated that the electronic will should contain the date and at least one characteristic validating the identity of the person. A characteristic to validate identity is defined as a unique property of that particular person. It has been stated that the biological view or physical movements of the person in question should be measurable or recognizable

\footnotetext{
Grant, p. 121-122.

10 Gerry W. Beyer and Claire G. Hargrove, "Digital wills: Has the time come for wills to join the digital revolution?", Ohio Northern University Law Review, no. 33 (2007), p. 895. Authors point out there is a consensus that many attorneys will not switch to an electronic medium to draft and store a will even if given a choice.

11 Necip Kocayusufpaşaoğlu, Miras hukuku (İstanbul, 1987), p. 191.

12 Available at: https://www.leg.state.nv.us/NRS/NRS-133.html

13 Grant, p. 108.

14 Banks, p. 301.
} 
from electronic records for this purpose. Fingerprints, retina scans, voice recognition, facial recognition and electronic signature are given as examples.

In our opinion, linking the validity of the electronic will to at least one feature that will allow validation of the identity of the person is well-directed. In the case where such a condition is not required, serious doubts may arise as to whether or not the e-will belongs to the testator. Therefore, any amendments to the Turkish Civil Code (hereinafter "TCC") regarding the e-will in legislation should include the conditional requirement of at least one characteristic that will allow validation of the identity of the person concerned.

In the regulations, it has also been accepted that there should only be one reliable copy of the electronic will and it should be protected by the testator or a reliable person designated by the testator. Moreover, it has also been required that, any trial for changes in the reliable copy should be easily identified. Also it has been determined that any copies from the reliable copy should allow identification of whether it is a reliable copy or not.

In NRS $§ 133.085$ (2), for competency to make an electronic will, the fulfillment of the age of 18 and having a sound mind is required. In the Electronic Wills Act Draft sec. 7, fulfilling the age of 18 is required whereas in Art.502 of TCC being over the age of 15 is enough to make a will. In our opinion, there is no need for a distinction in terms of the capability of making an electronic will. Indeed, in the provision of NRS $\S 133.020$, being over the age of 18 is also required for making a will using traditional methods. In other words, there are no differences in terms of the ability to make a will between the types of will. Therefore, the ability to make an electronic will should be assessed pursuant to Article 502 of TCC and it should be accepted that anyone over the age of 15 should be assumed to have the capability to make electronic will.

\subsection{Harmless Error Doctrine}

We have already mentioned that the first and only regulation for the electronic will is NRS $\S 133.085$. However, the harmless error doctrine should also be mentioned even if it is only related to the electronic will indirectly because, as can be seen below, ${ }^{15}$ the courts, which do not have a legal regulation for the electronic will, may accept electronic wills based on this rule. ${ }^{16}$

Pursuant to that doctrine, mentioned in the Uniform Probate Code (hereinafter "UPC") $§ 2-503,{ }^{17}$ a document, which is prepared without the observance of the

\footnotetext{
15 See Section 5 below.

16 Kyle B. Gee, “Beyond Castro's tablet will: Exploring electronic will cases around the world and re-visiting Ohio's harmless error statute", Probate Law Journal of Ohio, no. 4 (March/April 2016), p. 150.

17 "UPC § 2-503. Harmless Error. Although a document or writing added upon a document was not executed in compliance with Section 2-502, the document or writing is treated as if it had been executed in compliance with that section if the
} 
required forms may be applied as a valid will provided it is supported by "clear and convincing evidence". This rule has been accepted exactly or with some modification by ten states in the United States and has been made a domestic law. ${ }^{18}$

\subsection{Electronic Wills Act Draft}

The increase in the number of conflicts concerning the electronic will brought about the need for regulations on the issue. With this in mind, The National Conference of Commissioners on Uniform State Laws decided to establish a Committee for the preparation of a law regulating all aspects of the electronic will in October 2017.

As a result of the findings of the Committee, the Electronic Wills Act Draft emerged. ${ }^{19}$ The Draft, consisting of 15 sections, starts with the definitions and covers the form, attestation, validity conditions, and capability to make an electronic will as well as the regulations concerning witnesses. The Electronic Wills Act Draft also contains the harmless error rule. Section 4 of the Draft regulates the harmless error doctrine in line with UPC $\S 2-503$ and highlights that a document which is prepared without the observance of the required forms may be applied as a valid will, provided to be supported by "clear and convincing evidence".

Although looking promising for the future, the research of the Committee is incomplete. Moreover, to come into force, the Draft first has to be approved by the American Law Institute, and then needs to be accepted by each State.

\section{Case Law}

Under this heading, we will examine some of the judicial decisions in chronological order. Before doing so, we should note that even in common law, due to the lack of any legal regulation, there is resistance to the electronic will. ${ }^{20}$ The decisions that we will discuss below indicate that this resistance is broken. ${ }^{21}$

proponent of the document or writing establishes by clear and convincing evidence that the decedent intended the document or writing to constitute:

(1) the decedent's will,

(2) a partial or complete revocation of the will,

(3) an addition to or an alteration of the will, or

(4) a partial or complete revival of his [or her] formerly revoked will or of a formerly revoked portion of the will."

18 Gee, p. 150.

19 Available at: http://www.uniformlaws.org/shared/docs/electronic\%20wills/2018mar_EWills_Mtg\%20Draft.pdf

20 See e.g., Estate of Reed, 672 P.2d 829 (Wyo. 1983) (USA); Bekker v Naude 2003 (5) SA 173 (SCA) (South Africa).

21 See further details for case law: Kyle B. Gee, Electronic wills and the future: When today's techie youth become tomorrow's testators, available at: https://www.sssb-law.com/media/1140/chapter_1_gee_electronic_wills_and_the_future_2015_pliskin_2015918.pdf 


\subsection{Rioux v. Coulombe}

In "Rioux v. Coulombe" (1996), The Court upheld the admission to probate of a document that is contained on a computer disk. ${ }^{22}$ It is possible to summarize the decision as follows:

Rioux committed suicide, leaving an envelope containing a floppy disk and "This is my will/Jacqueline Rioux/1 February 1996" written on it. There was only one electronic file in the floppy disk and the unsigned document contained a set of orders and directives for after her death. The Court upheld that it did not meet the established requirements in Article 726 of the Quebec Civil Code. However, the Court found the electronic will to be valid under the dispensing power which would admit to probate wills that clearly stated the wishes of the testator. ${ }^{23}$

\subsection{MacDonald v. The Master}

In MacDonald v. The Master (2002), Supreme Court of Appeal of South Africa admitted to probate the document saved on computer. ${ }^{24}$ The subject of dispute for this decision is briefly: 25

In MacDonald, before committing suicide, the decedent left four notes in his own handwriting on a bedside table. One of the notes read, "I, Malcom Scott MacDonald, ID 5609065240106, do hereby declare that my last will and testament can be found on my PC at IBM under directory C:/WINDOWS/MYSTUFF/MYWILL/PERSONAL."” Although this document was incompliant with the formal conditions of wills, the Court, handling the case in terms of Wills Act Art.2/3, decided on probate of the will in accordance with the harmless error doctrine.

\subsection{Taylor v. Holt}

In Taylor v. Holt (2003), Court of Appeals of Tennessee admitted to probate an electronically signed document. ${ }^{26}$ It is possible to summarize the decision as follows: ${ }^{27}$

Taylor had electronically signed a one-page document containing his orders and directives after his death and printed out that document. Two neighbors of Taylor had signed with an ink pen this document by annotating that this was containing his directives after his death. Although the sister of the deceased had sued a case due to

\footnotetext{
Rioux v. Coulombe (1996), 19 E.T.R. (2d) 201 (Quebec Sup. Ct.) (Canada).

3 Nicholas Kasirer, "From written record to memory in the law of wills", Ottawa Law Review, no. 1 (1997), p. 43.

24 MacDonald v. The Master, 2002 (5) SA 64 (N) (South Africa).

5 See for details: Michael Cameron Wood-Bodley, "Macdonald v The Master: Computer files and the 'rescue' provisions of Wills Act”, The South African Law Journal, no. 121 (2004), p. 34 et seq.

26 Taylor v. Holt, 134 S.W.3d 830 (Tenn. Ct. App. 2003) (USA).

27 See for details: Chad Michael Ross, "Probate - Taylor v. Holt: The Tennessee Court of Appeals allows a computer generated signature to validate a testamentary will", The University of Memphis Law Review, no. 35 (2005), 603 et seq.
} 
the lack of a manual signature on the will, the court decided on probate of the will based on the following grounds:

\begin{abstract}
"The computer generated signature made by Deceased falls into the category of "any other symbol or methodology executed or adopted by a party with intention to authenticate a writing or record," and, if made in the presence of two attesting witnesses, as it was in this case, is sufficient to constitute proper execution of a will. Further, we note that Deceased simply used a computer rather than an ink pen as the tool to make his signature, and, therefore, complied with Tenn. Code Ann. § 32-1-104 by signing the will himself."
\end{abstract}

\title{
5.4 Estate of Javier Castro
}

The Ohio Court of Common Pleas, in its decision on the case Estate of Javier Castro (2012), admitted to probate a document written and signed on a digital screen. ${ }^{28}$ The subject of dispute for this decision is briefly as follows:

Castro, age 48, being in the hospital due to his illness, dictated his orders and directives after his death to his brother and he wrote them on a Samsung Galaxy tablet computer with a stylus pen. The brother, after writing the will in his handwriting, read it to Castro and then both Castro and his brother signed the document on the digital screen with the stylus pen. ${ }^{29}$

The Court accepted that the conditions of being "written" and "signed" pursuant to Ohio Revised Code (hereinafter "ORC”) § 2107.03 were available in this document; and admitted Castro's electronic will to probate based on ORC $\S 2107.24(\mathrm{~A})$, Ohio's modified version of the UPC's harmless error doctrine. Moreover, the decision also referred to the regulation of Nevada and stated that the will in question would be valid if made there. As a result, an electronic will handwritten and signed on such a tablet was admitted to probate.

\subsection{Mellino v. Wnuk\&Ors}

In Mellino v. Wnuk\&Ors (2013), Supreme Court of Queensland admitted to probate a video recording stored on DVD. ${ }^{30}$ Utilizing the harmless error doctrine, this court justified its decision as follows:

"I'm satisfied that the DVD is a document within the meaning of the section, and I'm also satisfied that the document embodies or was meant to embody the testamentary intentions of the deceased man. I think that is clear from the fact that he has written "my will" on the DVD itself and also from the substance of what he says in the video recording on the DVD. It is clearly made in contemplation of death, and the deceased man was found dead, having committed suicide, at some point after the video recording was made. He discusses

28 Estate of Javier Castro, Deceased, 2013-ES-00140 (Ct. Comm. Pl. Lorain Cnty., Probate Div., Ohio, June 19, 2013) (USA).

29 See for Javier Castro's electronic will: David Horton, "Tomorrow's inheritance: The frontiers of estate planning formalism", Boston College Law Review, no.58 (2017), p. 541-542.

30 Mellino v. Wnuk\& Ors [2013] SQC 336 (Supreme Court of Queensland) (Australia). 
his intention to suicide in the document. He is at some pains to define what property he owns, and it seems to me quite clear that, although very informal, what the document purports to do is to dispose of that property after death

Further, I am satisfied that the substance of the recording on the DVD demonstrates that the DVD itself without any more formality on the part of the deceased man would operate upon his death as his will. He comes very close to saying that exact thing informally, explaining that he's no good with paperwork and that he hopes that his recording will be sufficiently legal to operate to dispose of his property."

\section{Electronic Will in Turkish Law}

When we review the decisions, ${ }^{31}$ which consider the electronic will as a valid means, we see that such decisions were issued by the courts belonging to the common law. It would not be wrong to say that the strict formalities of the civil law tradition, to which the Turkish law belongs as well, block the validity of the electronic will. Indeed, the Federal Court of Switzerland upheld that where in a document the date and signature were written by hand, it was not accepted as a valid will just because the text was typed. ${ }^{32}$

In Turkish law, the principle of numerus clauses has been adopted in terms of the types of will and only three will types have been recognized: the official will, holographic will and oral will (TCC Art.531). Wills not complying with the formal requirements of these will types may be invalidated in accordance with the TCC Art.557. In the face of these explanations, it may be thought that the electronic will is not acceptable under current Turkish law $^{33}$ but the issue has to be reviewed in the context of each type of will. Therefore, this will be discussed separately below:

\subsection{Official Will}

An official will is made, in the presence of two witnesses, by a public official, magistrate, notary public or other person authorized to conduct such business (TCC Art.532). Since the official will can only be made with the participation of specific people and by a special procedural observance, it is not possible to be made electronically.

The Notary Act Art.198/A has permitted electronic signature in some processes. Therefore, if the official will was made in the presence of a notary, the question whether to use electronic signatures or not should be answered. Article 5 of the Regulation of Notaries Transactions on Electronic Medium, subject to a special provision, holds a parade official form or an electronic signature used in the legal process. Because an official will is a legal transaction and needs a formal procedure, the notary signing official held in probate is not possible with electronic signatures. ${ }^{34}$

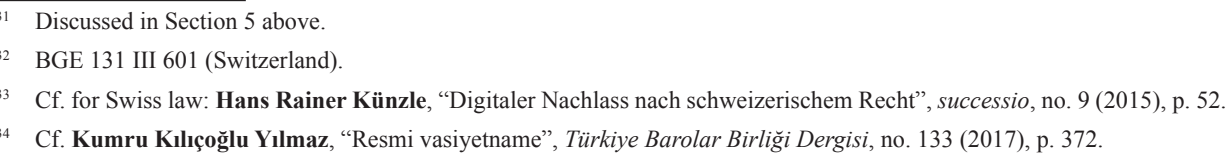


There is an electronic testamentary register of the notary association, which records only the electronic form of wills, which creates on paper as well, the electronic registration of wills in certain Communities of Switzerland. ${ }^{35}$ Although some projects ${ }^{36}$ similar to those in Switzerland have been prepared for allowing the citizens to make their wills through the portal of "e-devlet" (e-government) in Turkey, these are not legalized yet. ${ }^{37}$ Therefore, producing an electronic will in the form of an official will is currently not possible in Turkish law.

\subsection{Holographic Will}

A holographic will must be written in the testator's own hand from start to finish, include an indication of the day, month and year on which it is drawn up, and be signed by the testator (TCC Art.538). Since the holographic will should be written from the beginning to end of the will with the handwriting of the testator, it is not possible to accept a document to be prepared through a computer, or a tablet or a smartphone as a valid will, even if such document is signed with an ink pen after printing, the result will not change. Indeed, as mentioned above, the Federal Court of Switzerland adjudged the will as inapplicable despite the fact that the typed text was dated and signed manually. ${ }^{38}$

Thanks to advancing technology, it is possible to write on the screens of some tablets and computers with specially crafted pens. A tablet or computer converts the script into digital data (without any deformation and without converting it into another characters), and the hard drive stores it digitally. Since it was written by hand on a digital screen in such a way, it allows identification of the person. ${ }^{39}$ Presently, the distance between letters in a word, the slope of the letters, their connection to each other and the transitions are also available in a script written by hand on a screen just like in normal handwriting. ${ }^{40}$ Moreover, according to the provisions of TCC Art.538, there is no mandatory regulation regarding the place where the text of the will is written. For all these reasons, it is possible to accept an electronic will, written on a digital display, in terms of the current Turkish law. ${ }^{41}$ Even in this case, the will written on the screen of a tablet or a computer, should be written in the handwriting of the

\footnotetext{
35 http://www.testamentsregister.de/

36 Ahmet Tabanlığlu and Mehmet Emin Tenekeci and Süleyman Ali Çalışkan and Mehmet Akif Nacar, "Veraset Sistemine Yenilikçi Bir Yaklaşım: e-Vasiyet Servisi", available at: http://ab.org.tr/ab15/bildiri/363.pdf

37 LegalZoom, Nolo, and Rocket Lawyer are all websites that allow individuals to forego meeting with an attorney in person to draft last will and testament in United States. See https://www.legalzoom.com/; https://www.nolo.com/; https://www. rocketlawyer.com.

38 BGE 131 III 601 (Switzerland).

39 Cyril H. Hergenröder, "Testieren 2.0: Errichtung eines digitalen eigenhändigen Testaments mittels Touch- oder Smartpen?", Zeitschrift für Erbrecht und Vermögensnachfolge, no. 1 (2018), p. 7.

40 Halil Akkanat, "El yazısı ile vasiyetnamede vasiyetname metninin özellikleri”, Prof. Dr. Hayri Domaniç'e 80. Yaş Günü Armağanı (İstanbul, 2001), p. 806; Zekeriya Kurşat, "Yazılı șekil şartının unsuru olan imzanın elektronik ekrana atılmasını etkisi”, İstanbul Üniversitesi Hukuk Fakültesi Mecmuası, no. 1 (2017), p. 419; Savaş, p. 69.

41 Akkanat, p. 809; Savaş, p. 68; Doruk Gönen, El yazılı vasiyetname (İstanbul, 2007), p. 56.
} 
testator from beginning to end. Therefore, the document in the Castro case ${ }^{42}$ cannot be accepted as a valid will in terms of Turkish law because the document in question was not written by Castro.

Because of the ambiguity of the provision, the signature under the holographic will needs to be made by hand. In Article 5 of the Electronic Signature Act, the use of a secured electronic signature is not allowed in legal transactions subjected to an official form and formal procedure and collateral contracts excluding bank guarantees. ${ }^{43}$ In this regard, since the secure electronic signature does not provide the requirement of TCC Art. 538, the will is invalid. ${ }^{44}$ Therefore, if it is desired that the will, written on a digital screen, should be considered as a valid legal process, it must bear the manual signature. ${ }^{45}$ The case is also the same in the legislations of Germany ${ }^{46}$ and Switzerland ${ }^{47}$.

\subsection{Oral Will}

Whenever the testator is prevented from using any other form of will by extraordinary circumstances such as the imminent risk of death, breakdown in communications, epidemic or war, he or she is entitled to make a will in oral form (TCC Art.539). An oral will is an exceptional form, which is applicable in cases of extraordinary situations and where the other types of will cannot be done. However, exceptional cases mentioned in the provision are not restrictive but only exemplary.

In exceptional cases, if the testator communicates to the witnesses through audio or video applications can it be considered as a valid will? For example, if people were trapped in a collapsed mine at such a depth that they could not be heard, would contacting the people aboveground through wire line telephones or intercom like devices still be considered valid? ${ }^{48}$ In our opinion, such questions should be answered affirmatively. However, in such cases, the communication of the last will of the testator to two witnesses at the same time should be required. This is because if the last wishes are communicated to the witnesses at different times, it won't be easy to say which one should be accepted in the case of a difference between them. In this regard, if audio or video communication is possible in exceptional cases, this should occur in the form of a conference call.

\footnotetext{
42 Discussed in Section 5.4 above.

43 There is a similar provision in Ontario's Electronic Commerce Act S.O. 2000, c. 17, sec. 31. See Daniel A. Nelson, "The challenge of digital estate administration for executors", Estates, Trusts \& Pensions Journal, no. 32 (2012), p. 22 fn. 28 : "Ontario's Electronic Commerce Act. S.O. 2000, c. 17, s. 31 (1) specifically excludes wills, codicils and powers of attorney from its provisions. Thus any electronic of digital will is invalid." See further details for common law: Stephen Mason, Electronic signatures in law (London, 2016), N. 10.48 et seq.

44 Mustafa Dural and Turgut Öz, Miras hukuku (İstanbul, 2015), N. 421; Rona Serozan and Baki İlkay Engin, Miras hukuku (Ankara, 2014), p. 350; but see Savaş, p. 71 et seq.

45 Cf. Taylor v. Holt, 134 S.W.3d 830 (Tenn. Ct. App. 2003) (USA).

46 Hergenröder, p. 9.

47 Künzle, p. 52, leaves the question open for Swiss law.

48 Example set out by Savaş, p. 83-84.
} 
The other question to be answered under this heading is whether orders and directives of the person in exceptional cases after his or her death could be recorded as a video and/or audio file on an electronic device. Unfortunately, it is not possible to answer this question affirmatively in terms of de lege lata. It is not disputed that a video and/or audio file recorded on any device that can carry electronic data, such as a smartphone, is much more reliable than witnesses. We may say that this is not only regarding oral wills. In our view, a video file, where the person communicates his or her last wishes before death, is much more reliable for identifying the wishes of the testator, when compared to the types of will stipulated by law. ${ }^{49}$ For this reason, it would be fair to accept a video and/or audio file recorded de lege ferenda on an electronic device as a valid will. ${ }^{50}$

\section{Conclusion and Policy Recommendations}

The rapid development in information and communication technology impacts the traditional understanding of law and challenges its boundaries. Such transformation results in the emergence of conventional legal processes in unusual forms. For example, the electronic will is the modern form of a traditional legal procedure.

The electronic will is a practical and exceptionally favorable type of will that allows the testator to express his or her last wishes quickly, easily and free of charge. However, it should not be ignored that electronic wills reduce the caution and protective impact provided by formal procedures. Moreover, we also agree with the arguments that say that electronic wills are open to fraud and that no electronic medium is secure enough in terms of being hacked. However, the existence of risks should not lead to a ban on the electronic will, rather it calls for measures to be taken to eliminate those risks. We should also note that such risks are not peculiar to the electronic will, they are also present in the electronic signature, electronic contracts and electronic trade.

The Nevada State undertook the first and only legislation on the electronic will. Despite the criticisms, the aforementioned regulation is a pioneer and a groundbreaking step. In the legislations of other states (apart from Nevada State and the other countries within the common law tradition), the electronic will may be considered valid based on the harmless error doctrine. It is possible to say that the increase in legal conflicts connected with the electronic will encourages legislators to produce regulations in this regard. The Electronic Wills Act Draft has also arisen as a result of such a necessity.

\footnotetext{
Aybay, p. 34 fn. 2. Savaş, p. 80 fn. 139, takes a different view.

50 Affirmative: Estate of Wai Fun Chan, Deceased [2015] NSWSC 1107 (Supreme Court of New South Wales) (Australia); Mellino v. Wnuk\&Ors [2013] SQC 336 (Supreme Court of Queensland) (Australia); but see Estate of Reed, 672 P.2d 829 (Wyo. 1983) (USA).
} 
Since the principle of numerus clauses has been adopted in terms of the types of the will in Turkish law, the electronic will is only valid when it is made in an appropriate form prescribed by the Turkish Civil Code. However, case law clearly indicates that regulation on the electronic will is seriously and urgently required. The provisions regarding the will in the Turkish Civil Code were prepared over a hundred years ago and now they far from meet contemporary developments. In the face of rapidly improved technology, the laws must be reviewed in order to enable legal transactions made via electronic media. For this reason, the legislature must acknowledge that there is a legal gap regarding electronic wills -just like the electronic signature, electronic contracting, and the electronic general assembly- and make an effort to fill this gap. Considering the provisions of the Turkish Civil Code concerning the will, we propose a de lege ferenda text regarding the electronic will as follows:

"Article 531- A will may be made in an official form or through the handwriting of the testator, or in electronic or oral form."

\section{“3a. Electronic will}

Article 538a- (1) An electronic will can be made by using a device that allows to create, record and store data through electronic, optical or similar means.

(2) It is mandatory for an electronic will to contain at least one of the features such as fingerprints, retina scans, voice recognition, facial recognition or electronic signature that will allow authentication of a testator and to include an indication of the day, month and year on which it is made.

(3) An electronic will may be stored in an electronic medium that is created especially for that purpose." 


\section{Bibliography}

\section{Books and Journals}

Akkanat, Halil; "El yazısı ile vasiyetnamede vasiyetname metninin özellikleri”, Prof. Dr. Hayri Domaniç'e 80. Yaş Günü Armağanı (İstanbul, 2001), 799-815.

Aybay, Aydın; Miras hukuku dersleri (İstanbul 2002).

Banks, Jasmine; “Turning won’t into a will: Revisiting will formalities and e-filing as permissible solutions for electronic wills in Texas", Estate Planning \& Community Property Law Journal, no. 8 (2015), 291-315.

Beyer, Gerry W.; Hargrove, Claire G.; "Digital wills: Has the time come for wills to join the digital revolution?", Ohio Northern University Law Review, no. 33 (2007), 865-902.

Boddery, Scott S.; "Electronic wills: Drawing a line in the sand against their validity", Real Property, Trust and Estate Law Journal, no. 1 (Spring 2012), 197-212.

Dural, Mustafa; Öz, Turgut; Miras hukuku (İstanbul, 2015).

Gee, Kyle B.; "Beyond Castro's tablet will: Exploring electronic will cases around the world and re-visiting Ohio's harmless error statute", Probate Law Journal of Ohio, no. 4 (March/April 2016), 149-156.

Gee, Kyle B.; Electronic wills and the future: When today's techie youth become tomorrow's testators, available at: https://www.sssblaw.com/media/1140/chapter_1_gee_electronic_wills_ and the_future_2015_pliskin_2015918.pdf

Gönen, Doruk; El yazılı vasiyetname (İstanbul, 2007).

Grant, Joseph Karl.; "Shattering and moving beyond the Gutenberg Paradigm: The dawn of modern will”, University of Michigan Journal of Law Reform, no. 42 (Fall 2008), 105-140.

Hergenröder, Cyril H.; "Testieren 2.0: Errichtung eines digitalen eigenhändigen Testaments mittels Touch- oder Smartpen?”, Zeitschrift für Erbrecht und Vermögensnachfolge, no. 1 (2018), 7-11.

Horton, David; “Tomorrow's inheritance: The frontiers of estate planning formalism”, Boston College Law Review, no.58 (2017), 539-598.

Kasirer, Nicholas; "From written record to memory in the law of wills", Ottawa Law Review, no. 1 (1997), 39-61.

Kılıçoğlu Yılmaz, Kumru; “Resmi vasiyetname”, Türkiye Barolar Birliği Dergisi, no. 133 (2017), 369-392.

Kocayusufpaşaoğlu, Necip; Miras hukuku (İstanbul, 1987).

Kurşat, Zekeriya; "Yazılı şekil şarıının unsuru olan imzanın elektronik ekrana atılmasını etkisi", İstanbul Üniversitesi Hukuk Fakültesi Mecmuası, no. 1 (2017), 413-430.

Künzle, Hans Rainer; “Digitaler Nachlass nach schweizerischem Recht”, successio, no. 9 (2015), 39-54.

Mason, Stephen; Electronic signatures in law (London, 2016).

Nelson, Daniel A.; "The challenge of digital estate administration for executors", Estates, Trusts \& Pensions Journal, no. 32 (2012), 11-22.

Ross, Chad Michael; "Probate - Taylor v. Holt: The Tennessee Court of Appeals allows a computer generated signature to validate a testamentary will”, The University of Memphis Law Review, no. 35 (2005), 603-618. 
Savaş, Abdurrahman; "İnternet ortamında yapılan tek taraflı hukuki işlemler ve özellikle elektronik vasiyetname", Selçuk Üniversitesi Hukuk Fakültesi Dergisi, no.2 (2007), 51-91.

Serozan, Rona; Engin, Baki İlkay; Miras hukuku (Ankara, 2014).

Tabanlığlu, Ahmet; Tenekeci, Mehmet Emin; Çalışkan, Süleyman Ali; Nacar, Mehmet Akif; "Veraset Sistemine Yenilikçi Bir Yaklaşım: e-Vasiyet Servisi", available at: http://ab.org.tr/ab15/ bildiri/363.pdf

Wood-Bodley, Michael Cameron; "Macdonald v The Master: Computer files and the 'rescue' provisions of Wills Act”, The South African Law Journal, no. 121 (2004), 34-45.

\section{Websites}

http://ab.org.tr/

https://www.leg.state.nv.us/

https://www.legalzoom.com/

https://www.nolo.com/

https://www.rocketlawyer.com/

https://www.sssb-law.com/

http://www.testamentsregister.de/

http://www.uniformlaws.org/

\section{Cases}

Estate of Reed, 672 P.2d 829 (Wyo. 1983) (USA).

Rioux v. Coulombe (1996), 19 E.T.R. (2d) 201 (Quebec Sup. Ct.) (Canada).

MacDonald v. The Master, 2002 (5) SA 64 (N) (South Africa).

Bekker v Naude 2003 (5) SA 173 (SCA) (South Africa).

Taylor v. Holt, 134 S.W.3d 830 (Tenn. Ct. App. 2003) (USA).

BGE 131 III 601 (Switzerland).

Estate of Javier Castro, Deceased, 2013-ES-00140 (Ct. Comm. Pl. Lorain Cnty., Probate Div., Ohio, June 19, 2013) (USA).

Mellino v. Wnuk\&Ors [2013] SQC 336 (Supreme Court of Queensland) (Australia).

Estate of Wai Fun Chan, Deceased [2015] NSWSC 1107 (Supreme Court of New South Wales) (Australia). 
